\title{
Improvement in physical river habitat quality in response to river restoration measures
}

\author{
KATEŘINA KUJANOVÁ, MILADA MATOUŠKOVÁ
}

Charles University in Prague, Faculty of Science, Department of Physical Geography and Geoecology, Prague, Czechia; e-mail: k.smerousova@email.cz, milada.matouskova@natur.cuni.cz

ABSTRACT The main goal of this paper is to verify the hypothesis that application of appropriate restoration measures can lead to an improvement in river habitat quality and to achieve good hydromorphological conditions within the ecological status under the Water Framework Directive $2000 / 60 / E S$. The study includes an analysis of river network modifications founded on comparing historical and present-day maps, a determination of regional hydromorphological reference conditions based on a field survey and measurements, an assessment of hydromorphological quality of the studied water body and a proposal of appropriate restoration measures. The effects on improvement in hydromorphological status were predicted on the basis of a simulation of hydromorphological conditions after the application of proposed restoration measures. Overall, at least a good hydromorphological status would be achieved. The study proved that it is essential to carry out a hydromorphological survey including a determination of reference conditions as it provides some outputs necessary for a proposal and application of efficient restoration.

KEY WORDS hydromorphology - river restoration - river habitat quality - Slubice River - Water Framework Directive - HEM

KUJANOVÁ, K., MATOUŠKovÁ, M. (2016): Improvement in physical river habitat quality in response to river restoration measures. Geografie, 121, 1, 54-78.

Received July 2014, accepted November 2015.

(C) Česká geografická společnost, z. s., 2016 


\section{Introduction}

Increased use and anthropogenic modifications of rivers have brought the need to understand ecological impacts on a broad spectrum of changes of river habitats (Vaughan et al. 2009), and they have also brought a higher interest in their control and evaluation (Verdonschot 2000).

Approach to hydromorphological assessment should be based on understanding of the complex relations among fluvial morphology, hydrology and biological elements (Matoušková 2008a; Orr et al. 2008; Vaughan et al. 2009; Boon, Holmes, Raven 2010; Raven et al. 2010). A field survey has been the most preferred approach to hydromorphological data collection due to quality of its outcomes. Maps and aerial images document significant alterations (Weiss, Matoušková, Matschullat 2008; Vaughan et al. 2009).

As well as reference ecosystem is generally used in setting restoration project goals and later in its evaluation (Gann, Lamb 2006), the majority of European hydromorphological assessment methods under Water Framework Directive (WFD) are based on comparing the present conditions of rivers to the relevant regional reference conditions. Reference conditions are often provided in the sense of original or initial historical conditions; however, these, too, may have been exposed to the human impact (Dufour, Piegay 2009; Nestler et al. 2010) or to natural disturbances in the past. Thus although, the reference conditions of rivers and their floodplains indicate an ideal solution, any implementation of restoration measures depends on the present conditions, capacities and limitations of the today's European cultural landscape (Leuven, Nienhuis 2001; Matoušková 2005).

The basis for successful restoration lays in designation of a suitable morphological characteristics which create natural-like ecosystem that predestines hydraulic conditions and corresponds with the existing climatic and hydrological conditions and that can withstand extreme events as well as average conditions with minimal external assistance or subsidy (Wade et al. 2000; Just et al. 2005; Palmer et al. 2005; Gann, Lamb 2006). According to Gann, Lamb (2006) and Newson, Large (2006), this necessitates, in particular, the creation of self-sustaining river habitats, which should be incorporated in the surrounding landscape while Davis, Slobodkin (2004) and Palmer et al. (2005) emphasize the importance of supporting self-development of the river ecosystems. It is especially important to ensure balanced relations between management, protection and increasing value of the ecosystem (Gann, Lamb 2006; Hannah, Sadler, Wood 2007). An improvement of the ecological status is a priority in order to reduce the effects of climate changes (Alison 2007; Raven et al. 2010). Because a river should be understood as a continuum based on the River Continuum Concept (Vannote et al. 1980), the reaches above and below the restored segment which still remain degraded in terms of ecology, hydrology and geomorphology can have a negative impact on 
the restored segment (Matoušková 2008a). Water quality of the restored segment and even reaches above it should be considered as limiting factor for occurrence of biological elements (Jähnig et al. 2010, Sundermann et al. 2011).

The need to focus to a greater extent also on the riparian zone and the floodplain within the ecohydromorphological survey is emphasized (Zalewski 2006; Matoušková 2008b; Weiss, Matoušková, Matschullat 2008; Vaughan et al. 2009; Matoušková, Weiss, Matschullat 2010; McBride, Hession, Rizzo 2010; Šípek, Matoušková, Dvořák 2010). The potential for success of the river ecosystem restoration is increased by incorporating the floodplain in the restoration process (Lüderitz et al. 2004). The importance of the "river background" is manifested not only in assessment of the ecological status, but also in respect of flood protection. The extraordinary flood events resulted in the support of restorations and of using the retention area of floodplains as a suitable way to retain and reduce flood waves (Just et al. 2005, Jansen et al. 2006, Matoušková 2008b, Zalewski 2008).

This study includes analysis of river network modifications, a determination of regional hydromorphological reference conditions, and hydromorphological field survey in the case study river basin. The aim of this study was to produce on two segments of the main river within the study area a proposal of appropriate restoration measures for improvement of the hydromorphological status and prediction of its effect on the hydromorphological elements within ecological status under WFD. The hypothesis was that restoration of physical habitat of a channel and riparian belts can help to improve the hydromorphological status.

\section{Applied methods and data sources}

The analysis of changes in lengths and planform of the river network in the study river basin was based on comparing historical maps of Imperial Imprints of the Stable Cadastre of Bohemia from 1824-1843 in 1:2,880 scale and the present cadastral maps. The historical maps were georeferenced in GIS environment, and created vector layers were measured, evaluated in the tabular form, and compared to the maps of the present river network.

The Hydroecological monitoring - HEM (Langhammer 2007, 2008) methodology was applied to assess the present status of hydromorphological elements and the effect of proposed restoration measures. This methodology is compliant with the WFD and EN 14614 (CEN 2004) requirements and was accepted as the national methodology for the assessment of hydromorphological elements of ecological status for rivers in Czechia.

HEM methodology is based on the field survey of a river and its floodplain. The river under evaluation is divided in reaches of heterogeneous lengths and homogeneous nature based on the following indicators: planform, land cover of 
Table 1 - Overview of parameters assessed by HEM methodology, their dividing into mapped zones and their weight (Langhammer 2007, 2008)

\begin{tabular}{llc}
\hline Mapped zones & Parameters assessed & Weight of individual parameters \\
\hline Channel and planform & Planform modification & 0.30 \\
& Longitudinal continuity & 0.30 \\
& Variability of channel width & 0.10 \\
& Variability of depths in longitudinal profile & 0.15 \\
& Variability of depths in cross-section profile & 0.15 \\
\hline River bed & Channel bed forms & 0.30 \\
& River bed substrate & 0.20 \\
& Modification of river bed & 0.30 \\
& Extend of wood debris & 0.20 \\
\hline Bank and inundation area & Bank modifications & 0.30 \\
& Bank vegetation & 0.30 \\
& Riparian belt land cover & 0.25 \\
& Floodplain land cover & 0.15 \\
\hline Flow and hydrological regime & Flow character & 0.30 \\
& Hydrological regime alteration & 0.30 \\
& Lateral connectivity of river and floodplain & 0.20 \\
& Variability of discharge & 0.20 \\
\hline
\end{tabular}

Table 2 - Hydromorphological status classification (Langhammer 2008)

Levels of hydromorphological status (HS)

1 Very good

2 Good

3 Average

4 Poor

5 Destroyed
Hydromorphological quality value

$\geq<$

$1.0-1.7$
$1.7-2.5$
$2.5-3.5$
$3.5-4.3$
$4.3-5.0$

$1.7-2.5$

$2.5-3.5$

$4.3-5.0$

the riparian zone and floodplain, and bank modifications. The assessment uses a 5 point scale where 1 means the best score. HEM methodology considers 17 parameters in 4 mapped zones. An overview of parameters assessed according to HEM, weight of individual parameters and zonation is provided in Table 1. The different weight is set to represent the impact of parameters that are of major importance to hydromorphology of rivers. First, the value for each of 4 zones is calculated for individual reach of the river by using the weighted average of score of individual parameters. Then the overall hydromorphological quality value for each reach is calculated as the arithmetic mean of 4 zones (Langhammer 2008). The hydromorphological status classification is based on classification of calculated value of hydromorphological quality for each reach on the 5-level hydromorphological status (HS) according to Table 2. Hydromorphological status of a river corresponds 


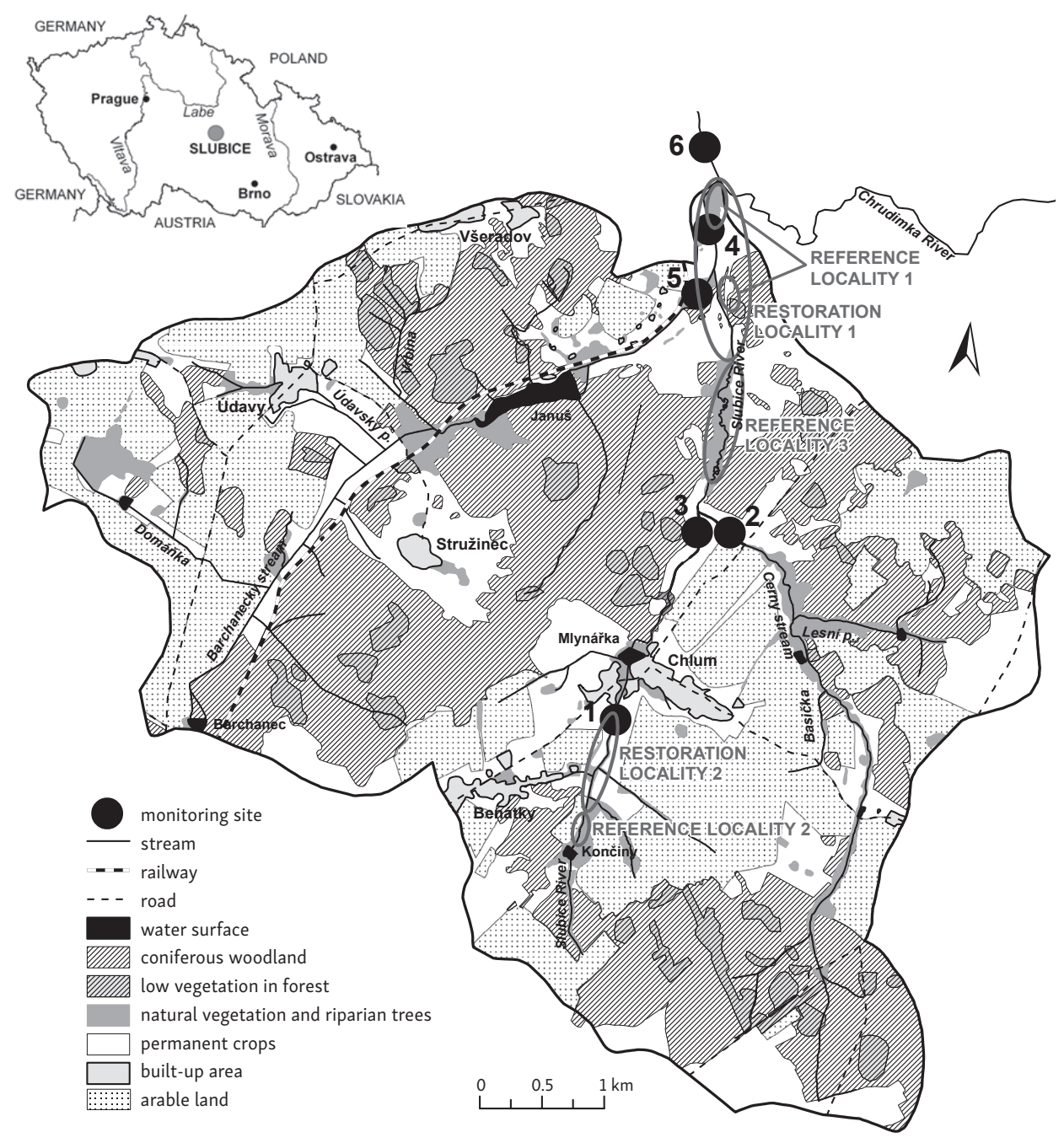

Fig. 1 - Location, monitoring sites of water quality and Land Cover of the Slubice River basin in 2009. Legend for monitoring sites: 1 - The Slubice River (upper), 2 - Černý stream, 3 - The Slubice River (middle), 4 - The Slubice River (lower), 5 - Barchanecký stream, 6 - The Chrudimka River. Source: aerial photos GEODIS 2009 and author's field survey.

to reference conditions if the very good hydromorphological status is achieved in the given reach, and at the same time, if none of the evaluated parameters reaches a value worse than 2 (Langhammer 2007).

Given that type-specific hydromorphological conditions in Czechia have not been determined, a determination of regional hydromorphological reference condition was a necessary prerequisite for formulating any proposal of restoration 
Table 3 - Monthly measurements of runoff variability in 6 profiles in study area in period 2008-2010 (MS - monitoring site)

\begin{tabular}{lllllll}
\hline Month & \multicolumn{7}{c}{$\mathrm{Q}\left(\mathrm{m}^{3} \cdot \mathrm{s}^{-1}\right)$} \\
\cline { 2 - 7 } & MS 1 & MS 2 & MS 3 & MS 4 & MS 5 & MS 6 \\
\hline November 08 & 0.010 & 0.016 & 0.031 & 0.046 & 0.007 & 0.455 \\
December 08 & 0.034 & 0.047 & 0.024 & 0.170 & 0.066 & 0.602 \\
\hline January 09 & 0.009 & 0.029 & 0.020 & 0.094 & 0.043 & 0.422 \\
February 09 & 0.023 & 0.046 & 0.041 & 0.178 & 0.084 & 1.454 \\
March 09 & 0.111 & 0.440 & 0.219 & 0.973 & 0.390 & - \\
April 09 & 0.039 & 0.084 & 0.113 & 0.378 & 0.140 & 1.095 \\
May 09 & 0.007 & 0.011 & 0.006 & 0.042 & 0.023 & 0.353 \\
June 09 & 0.009 & 0.032 & 0.021 & 0.089 & 0.047 & 0.528 \\
July 09 & 0.011 & 0.045 & 0.020 & 0.131 & 0.018 & 0.745 \\
August 09 & 0.014 & 0.020 & 0.044 & 0.095 & 0.051 & 1.016 \\
September 09 & 0.011 & 0.016 & 0.012 & 0.064 & 0.007 & 0.173 \\
October 09 & 0.007 & 0.007 & 0.007 & 0.018 & 0.006 & 0.127 \\
November 09 & 0.0385 & 0.0426 & 0.0623 & 0.2328 & 0.1158 & 1.0794 \\
December 09 & 0.0055 & 0.0746 & 0.0463 & 0.2637 & 0.1243 & 0.8715 \\
\hline January 10 & 0.0360 & 0.0871 & 0.0628 & 0.2092 & 0.0860 & 1.4119 \\
February 10 & 0.0207 & 0.0105 & - & 0.1021 & 0.0497 & 0.6987 \\
March 10 & 0.0319 & 0.0553 & 0.0634 & 0.1967 & 0.0685 & 0.7234 \\
April 10 & 0.1554 & 0.3516 & 0.4023 & 1.5224 & 0.6168 & - \\
May 10 & 0.0237 & 0.0388 & 0.0378 & 0.1598 & 0.0617 & 0.8144 \\
\hline
\end{tabular}

measures. Reference conditions were determined on the basis of detailed field survey and measurements of many hydromorphological characteristics in natural reaches of the selected river within the study area in 2008-2010. On the basis of field survey (GPS, leveling survey, electronic distance measuring instrument), meandering course and slope steepness were drawn. Runoff variability was measured by hydrometric propeller monthly in 6 profiles (monitoring sites in Fig. 1) in 2008-2010. Outputs of measurements are presented in Table 3 . Then individual cross-section profiles (across the whole floodplain) were surveyed and variability of width and depth, riffles and pools and substrate were recorded. Selected measured cross-section profiles, their maximum depth and bankfull area are presented in Figure 2. Channel capacity was derived from runoff variability measurements and recorded characteristics of cross-section profiles. At the same time, vegetation species in reference locality were recorded.

As a part of a restoration proposal it is necessary to take water quality into consideration. Therefore, in period autumn 2009 to summer 2010 every three months 12 basic physical-chemical and biochemical parameters were monitored (temperature, dissolved oxygen, $\mathrm{pH}$, conductivity, hardness, nitrite nitrogen, nitrate nitrogen, ammonium nitrogen, orthophosphates, COD-Mn, calcium, chlorides) based on standard chemical analyses. Water quality classes were determined 


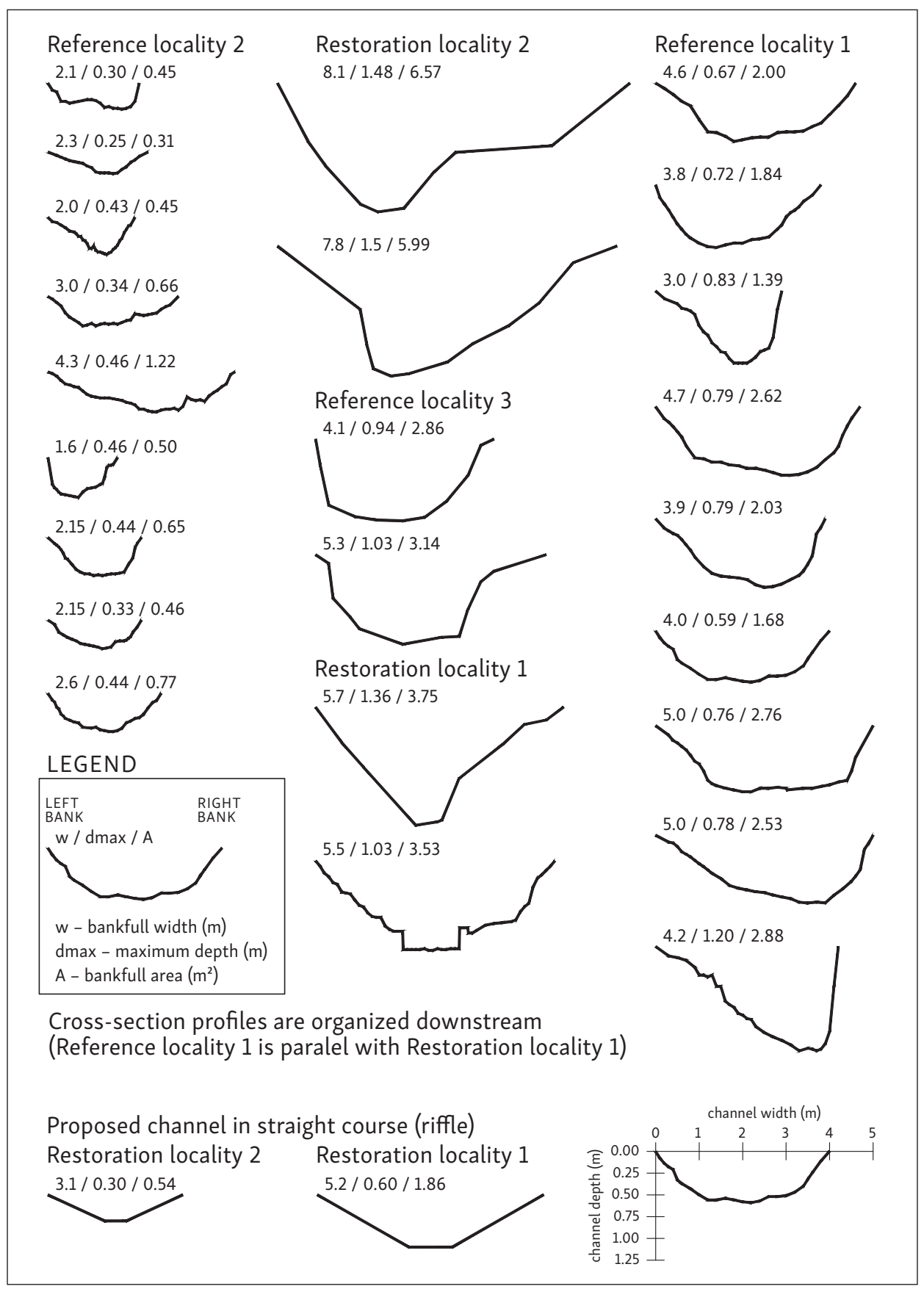

Fig. 2 - Selected measured cross-section profiles (their maximum depth and bankfull area) in reference localities and their comparison with present and proposed cross-section profiles in restoration localities 
in accordance with the Czech Norm ČSN 75 7221. Within the study river basin 6 profiles in total were monitored (monitoring sites in Fig. 1).

All results were interpreted in GIS environment (details in AutoCAD) whilst digital layers ZABAGED 1:10,000 (national geographical database) and aerial images (GEODIS) were used for background presentation.

\section{Study area}

The study area the Slubice River basin covers $29.21 \mathrm{~km}^{2}$ and is located in the northern edge of Vysočina region in triangle of towns: Havlíčkův Brod, Ždár nad Sázavou and Hlinsko (Fig. 1). The Slubice River is left site tributary of the Chrudimka River which is left site tributary of The Elbe River. The head spring of the Slubice River (lat $49^{\circ} 41.94^{\prime} \mathrm{N}$, long $15^{\circ} 51.36^{\prime} \mathrm{E}$ ) lays $617 \mathrm{~m}$ a.s.l. and the altitude at the confluence (lat $49^{\circ} 45.03^{\prime} \mathrm{N}$, long $15^{\circ} 51.73^{\prime} \mathrm{E}$ ) is $540 \mathrm{~m}$ a.s.l. The actual river length is $6.75 \mathrm{~km}$ and average annual discharge $\mathrm{Q}_{a}=0.32 \mathrm{~m}^{3} \cdot \mathrm{s}^{-1}$ (HMÚ 1970).

The highland type of landscape of the Slubice River basin is characterized by mixture of meadows, pastures, fields, forests and ponds. $51.5 \%$ of the river basin area is covered with forests; arable land represents $29.2 \%$ of the river basin area, while meadows and pastures represent only $16.7 \%$ (Fig. 1). The area belongs to rather cold, humid and windy parts of Czechia. The average annual temperature is $6^{\circ} \mathrm{C}$ and the average annual precipitation in the river basin is $879 \mathrm{~mm}$ (CHMI 2008).

The Slubice River was selected because its reaches vary between degraded and in natural conditions that deserve specific protection. Although the whole Slubice River basin was Protected Landscape Area, in the $2^{\text {nd }}$ half of the $20^{\text {th }}$ century $35 \%$ of the basin has been drained due to agricultural intensification and $49.8 \%$ of monitored streams have been modified (artificially stabilized). The study area thus provides reaches suitable for a determination of regional reference conditions as well as reaches with different anthropogenic pressures suitable for application of restoration measures and prediction of their effects.

Selection of localities suitable for proposing restoration measures was based on the essential idea of restoring reaches of the worst hydromorphological status where the highest potential effect of status improvement could be achieved. The channel deepening, bank reinforcement, the runoff situation and gradient of the river bed (unsuitable straightening) were decisive for necessity of restoration and creation of self-sustaining river habitats. Important was to connect the restored reaches to the natural reaches of the stream above, which were used as reference localities (Figs. 1, 3), and use of unused and wet properties in floodplain for creation of a new channel. Based on assessment of all the aspects above, two segments of the Slubice River were selected for the restoration measures proposal, Restoration 


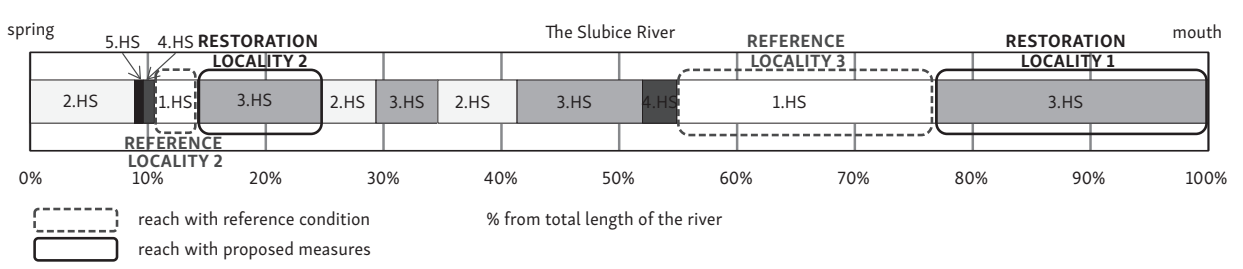

Fig. 3 - Outputs of hydromorphological status assessment of the Slubice River using HEM methodology (Langhammer 2007, 2008), drawn in longitudinal profile of Slubice River

locality 1 (lat $49^{\circ} 45.00^{\prime} \mathrm{N}$, long $15^{\circ} 51.74^{\prime} \mathrm{E}$; lat $49^{\circ} 44.40^{\prime} \mathrm{N}$, long $15^{\circ} 51.93^{\prime} \mathrm{E}$ ), and Restoration locality 2 (lat $49^{\circ} 42.97^{\prime} \mathrm{N}$, long $15^{\circ} 51.52^{\prime} \mathrm{E}$; lat $49^{\circ} 42.46^{\prime} \mathrm{N}$, long $15^{\circ} 51.39^{\prime} \mathrm{E}$ ). The uniqueness of Restoration locality 1 lays in existence of preserved meanders of former channels - Reference locality 1 in the floodplain (Fig. 4), which were not filled and destroyed due to low accessibility of the terrain. These former channels were used for determination of regional reference conditions (course, gradient of the river bed, shape of cross-section profiles, channel capacity, etc.), and were included in the resulting proposed channel (Figs. 4, 5). Such proposal means restoration of flow regime through the former channels. Restoration locality 2 was

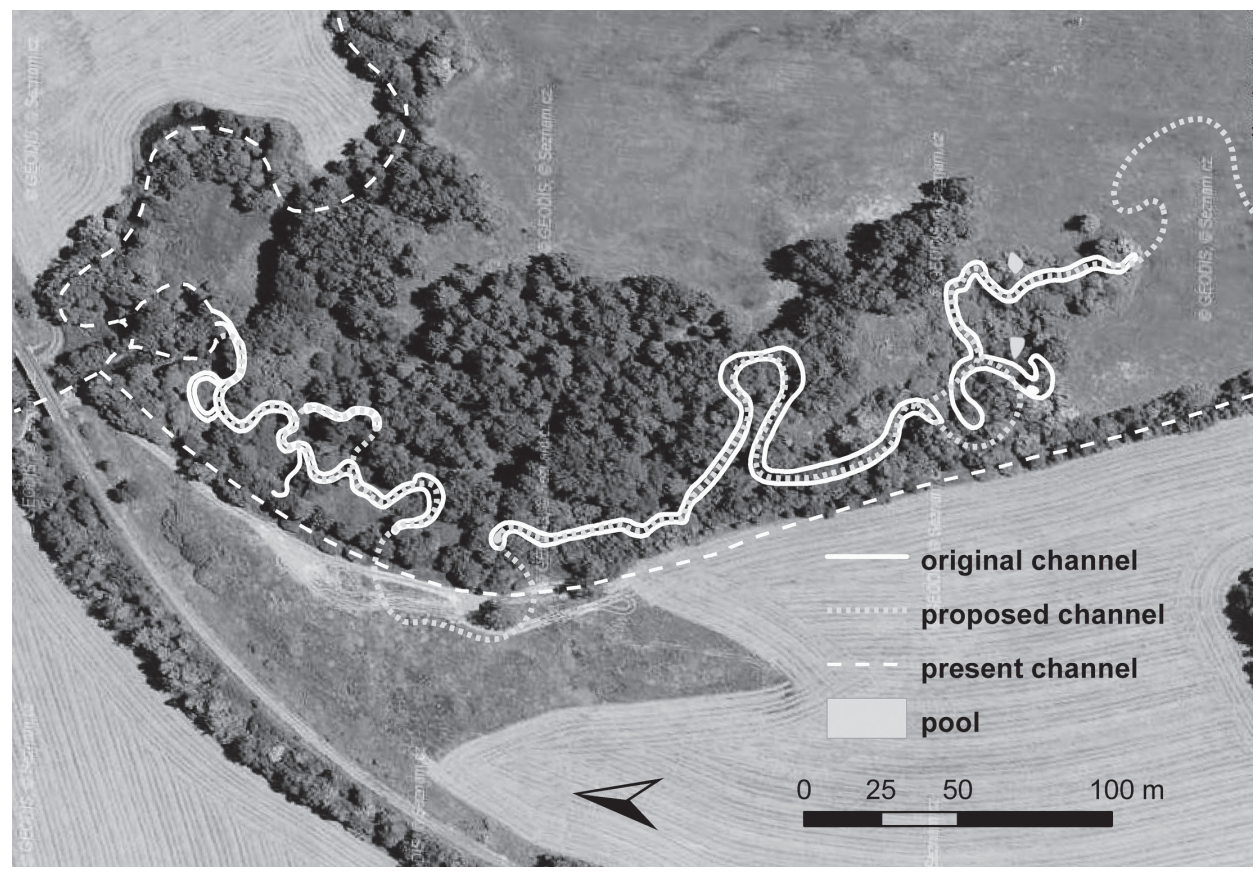

Fig. 4 - Aerial photo of a section of Reference locality 1 and Restoration locality 1 - former channel detail, proposed connection of former channels and present channel course. Source: aerial photos GEODIS 2009. 

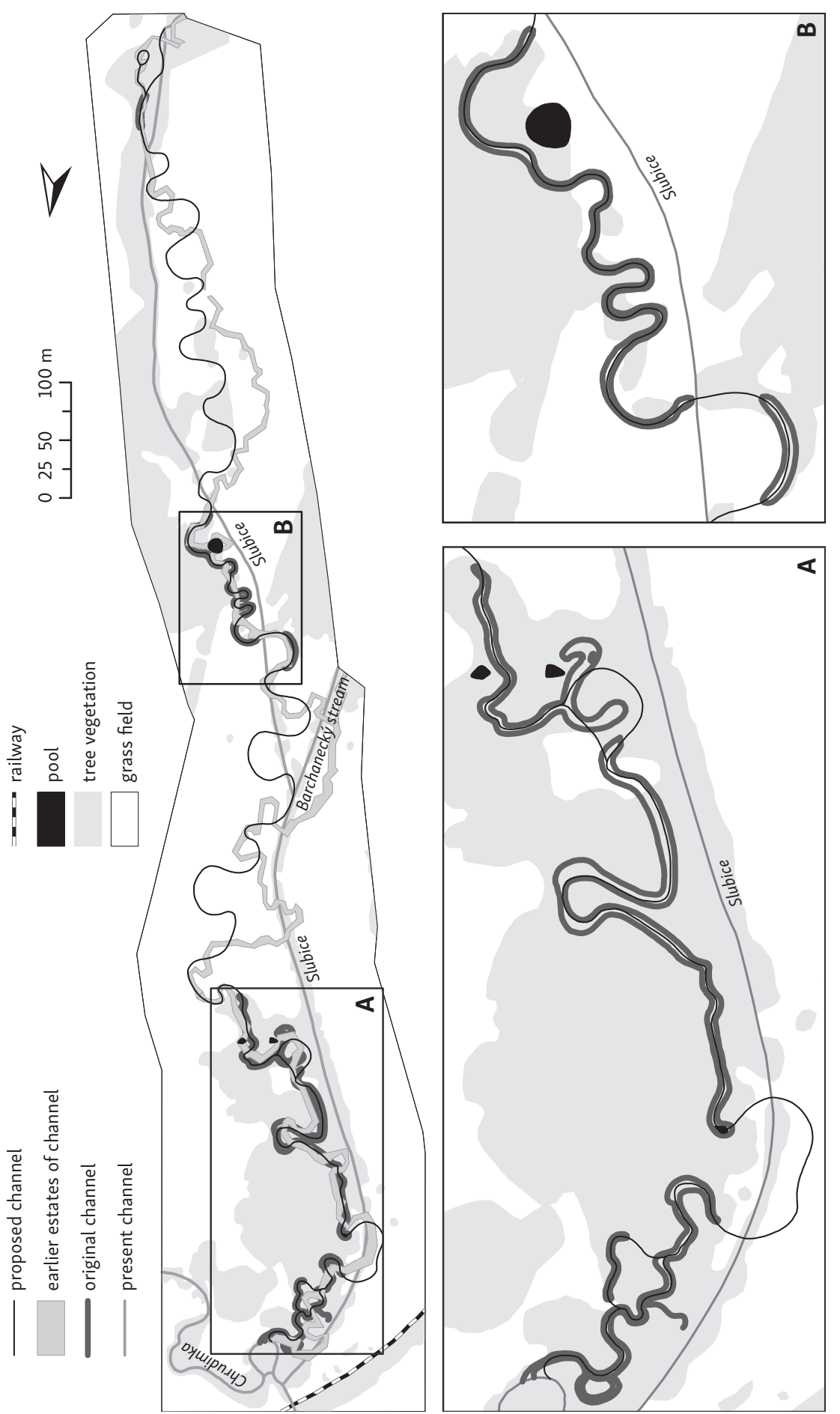

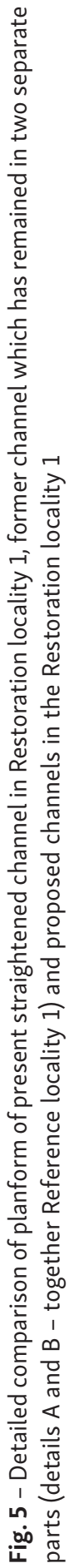


Table 4 - Comparison of main characteristics of restoration and reference localities including reach of the Slubice River where partially restoration was realized in period 1997-1999

\begin{tabular}{|c|c|c|c|c|c|}
\hline Characteristics & $\begin{array}{c}\text { Restoration } \\
\text { locality } 1\end{array}$ & $\begin{array}{l}\text { Reference } \\
\text { locality } 1\end{array}$ & $\begin{array}{c}\text { Restoration } \\
\text { locality } 2\end{array}$ & $\begin{array}{l}\text { Reference } \\
\text { locality } 2\end{array}$ & $\begin{array}{l}\text { Reach, where } \\
\text { partially } \\
\text { restoration was } \\
\text { realized }\end{array}$ \\
\hline Channel length & $1,237 \mathrm{~m}$ & $450 m$ & $1,046 \mathrm{~m}$ & $480 m$ & $689 m$ \\
\hline $\begin{array}{l}\text { Channel course } \\
\text { modification }\end{array}$ & $\begin{array}{c}\text { Shortening about } \\
48.8 \%\end{array}$ & $\begin{array}{c}\text { Natural } \\
\text { meandering } \\
\text { course }\end{array}$ & $\begin{array}{c}\text { Shortening about } \\
31.4 \%\end{array}$ & $\begin{array}{l}\text { Natural } \\
\text { meandering } \\
\text { course }\end{array}$ & Straightening \\
\hline Channel width & Cca 4.5-6m & Cca 4-5 m & Cca 6-8 m & Cca 2-2.5 m & Cca $1.2-1.6 \mathrm{~m}$ \\
\hline Channel depth & Cca 0.9-1.4 m & Cca $0.7-0.8 \mathrm{~m}$ & Cca 1-1.5 m & Cca $0.3-0.5 \mathrm{~m}$ & Cca 0.5-1.2 m \\
\hline $\begin{array}{l}\text { Reinforcement } \\
\text { of river bed } \\
\text { and bank }\end{array}$ & $\begin{array}{c}\text { Concrete blocks } \\
\text { or wooden bars } \\
\text { stabilized by } \\
\text { metal stakes in } \\
\text { banks; artificial } \\
\text { substrate of river } \\
\text { bed }\end{array}$ & $\begin{array}{l}\text { Preserved } \\
\text { meanders } \\
\text { without } \\
\text { reinforcement }\end{array}$ & $\begin{array}{l}\text { Wooden bars } \\
\text { stabilized by } \\
\text { metal stakes in } \\
\text { banks }\end{array}$ & $\begin{array}{l}\text { Meanders } \\
\text { without } \\
\text { reinforcement }\end{array}$ & $\begin{array}{l}\text { Wooden bars in } \\
\text { banks; artificial } \\
\text { substrate of river } \\
\text { bed }\end{array}$ \\
\hline Channel capacity & Cca $4.3 \mathrm{~m}^{2}$ & Cca $2.5 \mathrm{~m}^{2}$ & $\begin{array}{l}\text { Deepening, } \\
\text { cca } 7.4 \mathrm{~m}^{2}\end{array}$ & Cca $0.6 \mathrm{~m}^{2}$ & Cca $1.5 \mathrm{~m}^{2}$ \\
\hline $\begin{array}{l}\text { Vegetation of } \\
\text { floodplain }\end{array}$ & Wet meadow & Natural forest & Meadow & Natural forest & Meadow \\
\hline $\begin{array}{l}\text { Quality of zone } \\
\text { channel and planform } \\
\text { (HEM) }\end{array}$ & 4 & 1 & $3-4$ & 1 & 4 \\
\hline $\begin{array}{l}\text { Quality of zone river } \\
\text { bed (HEM) }\end{array}$ & $3-4$ & $1-2$ & $3-5$ & 1 & 4 \\
\hline $\begin{array}{l}\text { Quality of zone bank } \\
\text { and inundation (HEM) }\end{array}$ & $2-3$ & 1 & $2-3$ & 1 & $2-3$ \\
\hline $\begin{array}{l}\text { Quality of zone flow } \\
\text { and hydrological } \\
\text { regime (HEM) }\end{array}$ & $2-3$ & 1 & $2-3$ & 1 & $2-3$ \\
\hline $\begin{array}{l}\text { Overall } \\
\text { hydromorphological } \\
\text { quality (HEM) }\end{array}$ & 3 & 1 & $2-3$ & 1 & 3 \\
\hline
\end{tabular}

chosen particularly for considerable deepening and continuing deep erosion of the straightened channel associated with a drainage effect, and dangerous residues of channel stabilization. Comparison of main characteristics of restoration localities and reference localities is presented in Table 4 . As an example a restored reach of the Slubice River is included. This partial restoration was realized in period 1997-1999 and occurred only within the modified channel using biotechnical measures, e.g. the obstacles and wooden reinforcement. A channel course was not restored. The partial restoration did not improve the classification of the hydromorphological status. 


\section{Results}

\subsection{Changes in the river network length and shape}

Determination of the original course of the streams in the Slubice River basin before their modification and evaluation of the changes in the length and shape of the river network proved considerable shortening (Fig. 6). The calculation shows shortening by $31 \%$ in upper course of the Slubice River (reach Slubice_1, Figs. 6, 7), and $48.8 \%$ in the lower course (reach Slubice_4, Figs. 6, 7). Such a level of river network shortening is higher than the Czech average of river network modification - 28.4\% (Langhammer, Vajskebr 2007). The main reasons for modifications done in the past were to drain the landscape in order to intensify agriculture and flood protection of arable land in the floodplain.

\subsection{Hydromorphological status}

The overall hydromorphological status of the Slubice River assessed by using the HEM methodology can be denoted as average hydromorphological status (3. HS); average hydromorphological status was determined for $49.5 \%$ of the length of mapped reaches (Fig. 3) located in area used for agricultural practices, where the channel was straightened and bank stabilized. $25.7 \%$ of the river length were in very good status (1. HS) represented by reaches with near natural habitat of riverine ecosystem, which can be considered as referential (Fig. 3). In good hydromorphological status (2. HS) was assessed $20.2 \%$ of the total evaluated length of the river.

\subsection{Water quality}

Contamination by nutrients, particularly nitrates, was found to be the most important problem of water quality in all the monitored profiles (Fig. 1). In all evaluated profiles the nitrates achieved the worst recorded value of the worst quality class (V) pursuant to Czech Norm ČSN 757221 (Table 5, Fig. 8). The highest concentration of $\mathrm{N}^{-\mathrm{NO}_{3}^{-}}$corresponds to higher discharge which indicates inappropriate use and application of industrial fertilizers and manure. On the other hand $\mathrm{N}-\mathrm{NH}_{4}^{+}$ achieved quality class II or III in all profiles in the Slubice river basin (Table 5, Fig. 8). In this case the highest concentration corresponds to low discharge which indicates communal sewerage water pollution. (Only profile on the Chrudimka River - MS 6 (Fig. 1) achieved quality class V.) Organic contamination is also a problem of water quality, represented by the COD-Mn parameter (class IV in most 


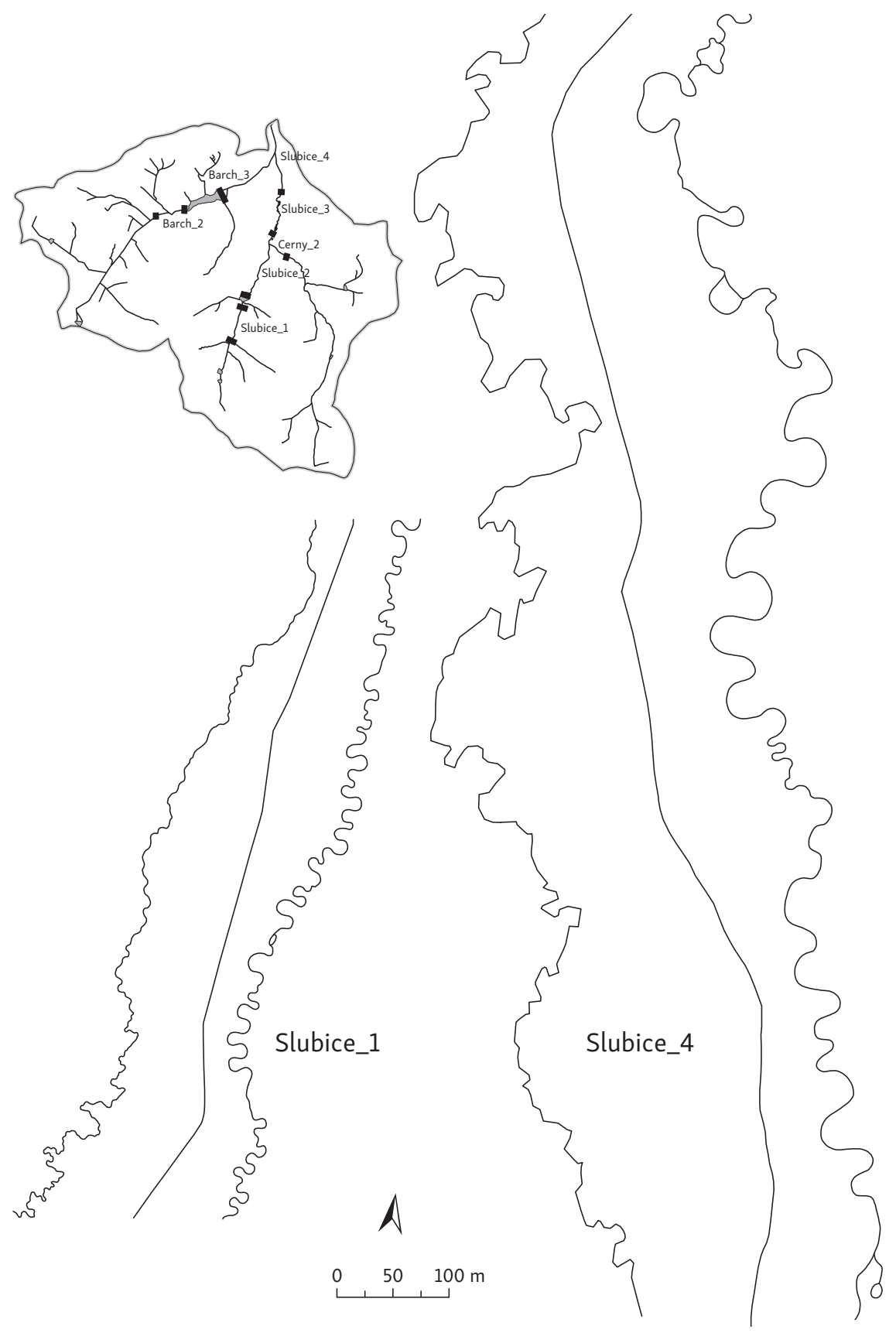

Fig. 6 - The changes in the length and shape of the 2 selected reaches (reach Slubice_1 in Restoration locality 2, reach Slubice_4 in Restoration locality 1). Comparison of the original course from historical maps (in left) with the present course from cadastral maps (in the middle) and with the proposed course (in right). 


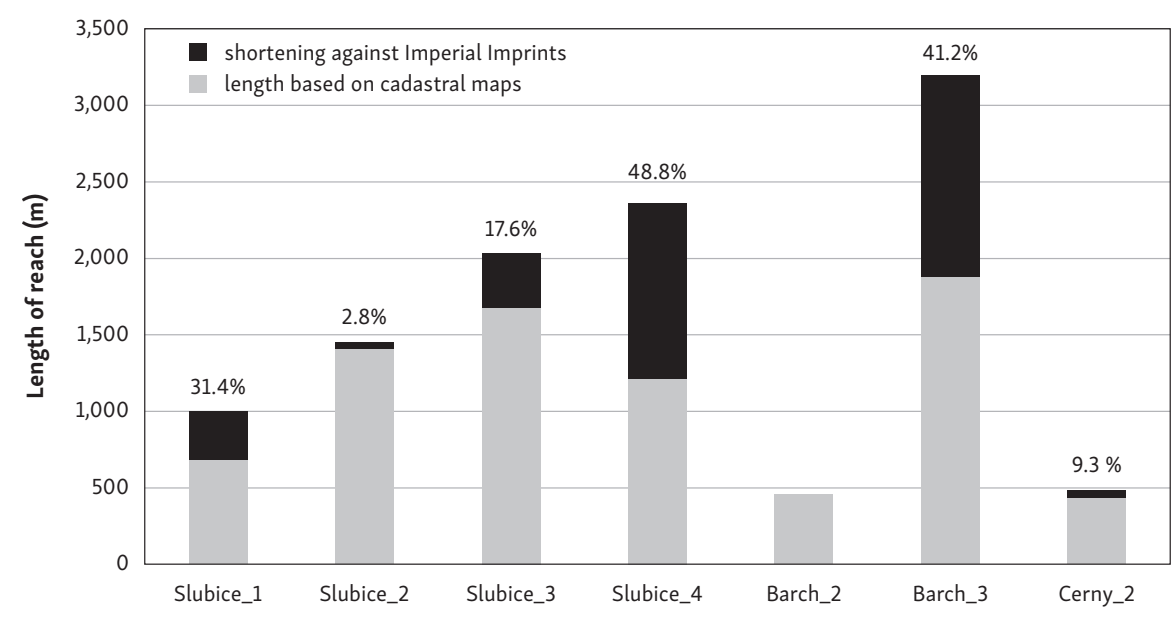

Fig. 7 - Present length based on cadastral maps (grey) and changes in comparison of former length from historical maps (black) of 7 selected reaches of river network in the Slubice River basin. Selected reaches ( 4 on the Slubice River, 2 on Barchanecky stream, 1 on Cerny stream) were numbered from spring to mouth (Fig. 6).

profiles); on the contrary, dissolved oxygen shows sufficient concentrations in water (Table 5). Poor water quality (quality class IV and V) can have a negative impact on occurrence of biological elements and ecological status. Water quality in study area shows little differences between individual monitoring sites (except for MS 6 which is on larger river with many tributaries and below sewage treatment plant) but considerable differences in seasonal concentrations and in relation to discharge.
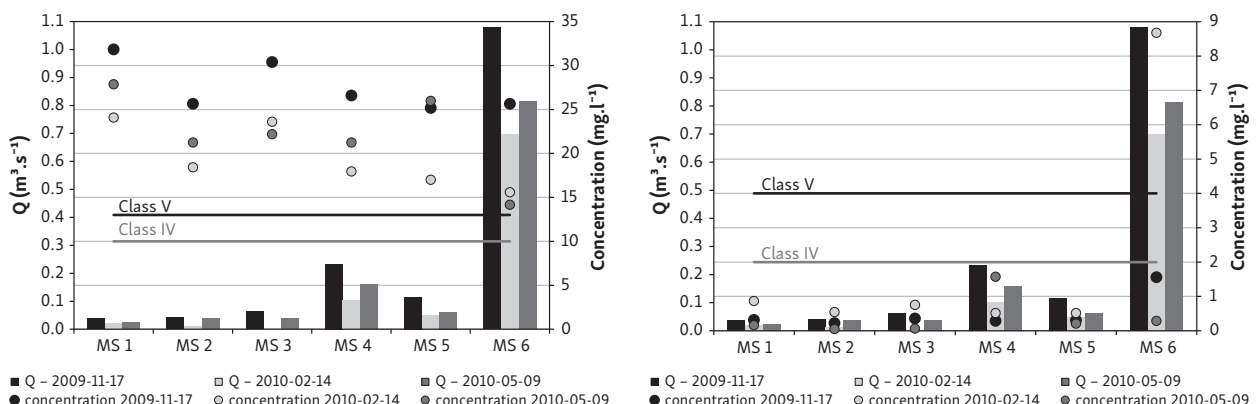

Fig. 8 - Dependence between concentration of $\mathrm{N}^{-\mathrm{NO}_{3}^{-}}$(in left), $\mathrm{N}-\mathrm{NH}_{4}^{+}$(in right) and corresponding measured discharge in monitoring sites (threshold values for quality classes IV and $\mathrm{V}$ according to Czech Norm ČSN 757221 are highlighted) 

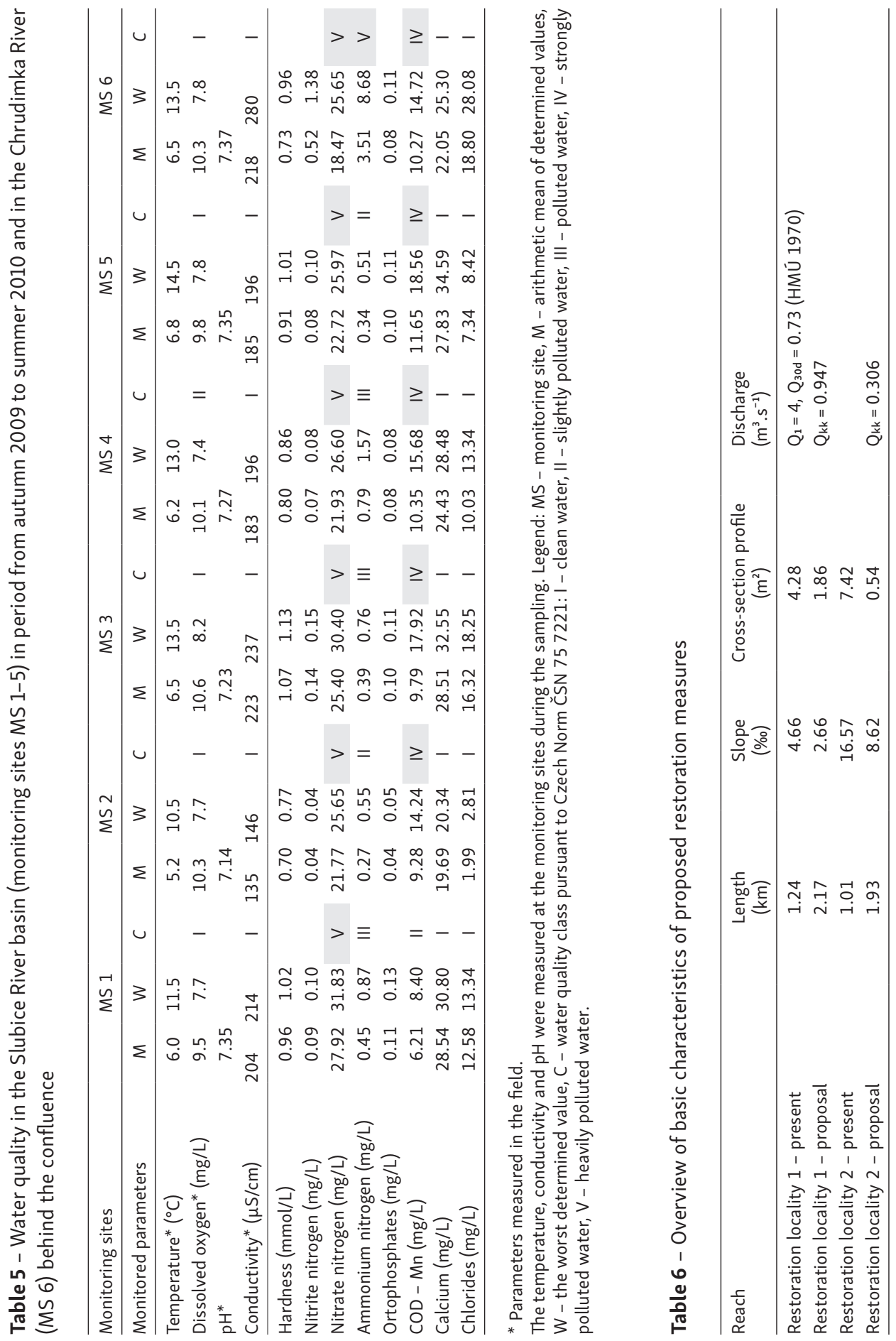


\subsection{Restoration proposal}

According to assessment by HEM and characteristics recorded during the field survey, channel modifications (straightening, deepening and reinforcement) are the worst problems of the Slubice River basin while the floodplain shows good functionality (communication between channel and floodplain, retention) and is in relatively good state (land use). The main aim of the restoration was to propose appropriate slope steepness of the river bed (it means enhancement of the channel's length) and channel capacity (including width versus depth). Thus a new meandering channel course was proposed in both localities based on parameters of longitudinal and cross-section profiles measured in relevant reference reaches. Selected cross-section profiles of reference localities and their comparison with cross-section profiles in restoration localities and proposed cross-section profiles are presented in Figure 2. Cross-section profiles in both reference localities are shallow, wide and show significantly higher variability in shape and depth. Reference locality 2 has several times smaller bankfull area in comparison with cross-section profiles in both restoration localities.

The proposal also included special specifications: (1) new course should run along the valley floor using preserved traces of the former natural channel including the riparian zone vegetation (Restoration locality 1, Figs. 4, 5), (2) incorporation of drainage outlets in the proposal (Restoration locality 2), and (3) consideration of availability of properties for implementation of the proposal (both restoration localities).

The course length would almost double in both restoration localities (Figs. 5, 6), while the average gradient of the river bed would become reduced by almost one half (see Table 6). The floodplain in both restoration localities is formed by extensively used meadows, therefore a near-natural, wide and shallow channel was proposed with the depth-to-width ratio 1:5.2 for Restoration locality 1 (or 1:6 for Restoration locality 2, respectively), with $\mathrm{Q}_{30 \mathrm{~d}}$ capacity and discharge $0.947 \mathrm{~m}^{3} . \mathrm{s}^{-1}$ in Restoration locality 1 and with $\mathrm{Q}_{30 \mathrm{~d}}$ to $\mathrm{Q}_{1}$ capacity and discharge $0.306 \mathrm{~m}^{3} . \mathrm{s}^{-1}$ in Restoration locality 2 (Table 6; Fig. 2). For proposed cross-section profiles in both restoration localities rating curves were calculated (Fig. 9). The former channel of the stream on the right side of the inundation area - Reference locality 1 was included in the proposal in Restoration locality 1 (Fig. 5).

It was also proposed to complete existing vegetation with protective bank vegetation in order to stabilize the new channel, and with group riparian vegetation in the floodplain so that the restoration incorporates into the surrounding landscape.

Prediction of hydromorphological status after the proposed restoration: The effectiveness of realized restoration is given by approaching natural (regional reference) status of the river ergo by its complexity. This study simulated whether restoration 

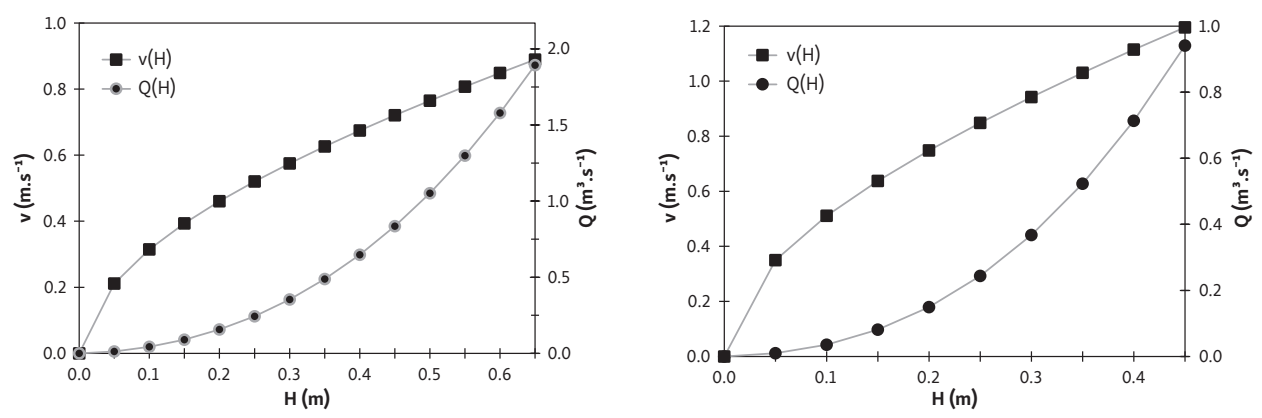

Fig. 9 - Rating curves and velocity curves for proposal cross-section profiles in straight course (riffle) for Restoration locality 1 (in left) and for Restoration locality 2 (in right)

proposed with the use of maximum area potential in favour to natural river character (reference status) will result in improvement of all major parameters of HEM methodology thus how the restoration will affect the overall hydromorphological status of the river evaluated in accordance with Water Framework Directive (2000/60/ES).

Based on assessment of the present hydromorphological status and on simulation of conditions after application of the proposed restoration measures, real risks were predicted, which follow from restorations of river channels. The risks prediction was based on assessed parameters which are the most significant for the resulting effect (Table 7).

The primary hypothesis said that complying with all the rules above to propose the restoration measures, implementation of the proposed restoration measures should lead to provable improvement of the river habitat quality, and to the achievement of good hydromorphological status in both study localities. Criteria of successful restoration, which leads to improvement of hydromorphological elements, were selected on the basis of assessment setting of HEM methodology (Langhammer 2008). Expected risks and effects of proposed restoration were estimated from outputs of restoration realizations (for example Just et al. 2005; Kliment et al. 2008). Then, hydromorphological status for expected status was calculated.

Application of the HEM methodology on the simulated conditions that should be achieved through the proposed and implemented remedial measures demonstrated the most significant improvement in the zone of the channel itself, as expected - by up to 3 classes of hydromorphological status (Fig. 10). In connection with improvement of morphological characteristics of the channel, improvement by 1-2 classes within the hydrological regime zone is also achieved (Fig. 10). Significant improvement was caused by restoration of river continuity in longitudinal profile, variability of depth and elimination of river bed modification and bank 
Table 7 - Potential risks and effects of realization of the proposed restoration measures on individual assessed hydromorphological parameters

\begin{tabular}{|c|c|c|}
\hline $\begin{array}{l}\text { Parameters which will be } \\
\text { significantly improved }\end{array}$ & $\begin{array}{l}\text { Parameters that may be at risk } \\
\text { or temporarily deteriorated }\end{array}$ & $\begin{array}{l}\text { Parameters without significant } \\
\text { changes }\end{array}$ \\
\hline $\begin{array}{l}\text { Planform modification } \\
\text { River continuity in longitudinal } \\
\text { profile } \\
\text { Variability of depth in cross-section } \\
\text { profile (it depends on realization of } \\
\text { terrain work) } \\
\text { Modification of the river bed, } \\
\text { connection to ground water bodies } \\
\text { Bank modification } \\
\text { Character of water flow }\end{array}$ & $\begin{array}{l}\text { Variability of channel width } \\
\text { (it depends on realization of terrain } \\
\text { work) } \\
\text { Variability of depth in longitudinal } \\
\text { profile (it depends on realization } \\
\text { of terrain work and precipitation } \\
\text { events after the realization) } \\
\text { Bank stability } \\
\text { River bed substrate (diversity) } \\
\text { Extend of wood debris } \\
\text { Bank vegetation } \\
\text { Channel bed forms }\end{array}$ & $\begin{array}{l}\text { Riparian belt land cover } \\
\text { Floodplain land cover } \\
\text { Hydrological regime alteration } \\
\text { (abstraction and discharge) } \\
\text { Lateral connectivity of river and } \\
\text { floodplain } \\
\text { Variability of discharge }\end{array}$ \\
\hline
\end{tabular}

modification, restoration of planform reference conditions and character of water flow (Table 7). Improvement of the status of the inundation area zone by 1 class is influenced by incorporation of bank modifications in this zone. As the Table 7 shows, improvement of some parameters (middle column) are dependent on a quality of realization (variability of channel width, variability of depth in longitudinal profile) or are developed in a longer period (diversity of river bed substrate, channel bed forms, bank stability and vegetation) which could be affected by flood events. Figure 10 shows results for Restoration locality 1; however, similar results are also achieved by the restoration proposal in Restoration locality 2. Implementation of the proposed restoration measures at least a good hydromorphological status would be achieved in both study localities (Fig. 10).

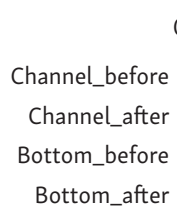

Bank and inundation area_before

Bank and inundation area_after

Flow and hydrological regime_before

Flow and hydrological regime_after Summary state_before Summary state_after

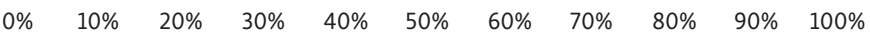

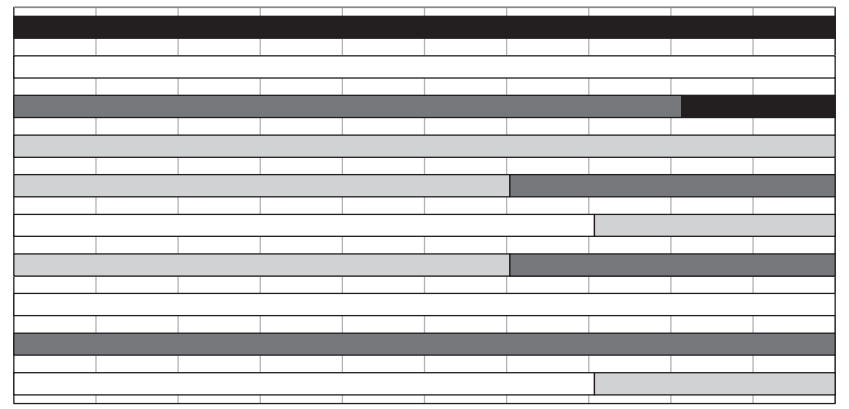

$\square 1$.HS (very good status)

$\square$ 2.HS (good status)

3.HS (average status)

4.HS (poor status)

Fig. 10 - Hydromorphological status of the Slubice River in Restoration locality 1 assessed by using HEM methodology (Langhammer 2007, 2008) - present state and prediction of the state after restoration with details of individual mapped zones and the overall status 


\section{Discussion}

Outputs obtained by using HEM methodology provide detailed evaluation of morphological characteristics of the channel, of the range of river network modifications and of alteration of the hydrological regime, quality and use of the riparian zone and floodplain. Determination of hydromorphological reference conditions enables to set the target status for the locality. However, within the complex ecohydrological survey it is necessary to add hydrobiological survey to hydromorphological and the basic physical-chemical parameters monitoring. Only ichtyological survey was carried out in the study river basin, focused on the quality of the habitat for fish populations (Rozkošný et al. 2007). No further hydrobiological surveys were performed as part of this study focused on the hydromorphological situation and especially on the channel course due to time capacity reasons.

Kliment et al. (2008) evaluated the development of the channel of Sviňovický brook restored in 2005 - by freeing the channel in its original course. The channel showed a deepening process in the first 6 months after its restoration; however, in the subsequent period it already exhibited especially positive bank erosion and spontaneous development of small meanders which implicated increased variability of the bed widths and depths (presence of riffles and pools), provoked erosion and accumulation processes and increase of the substrate diversity. Very important event was the flood on July 12, 2006 which initiated intensive fluvialmorphological processes: mild to moderate deepening (up to $30 \mathrm{~cm}$ ) associated with the broadening (up to $20 \mathrm{~cm}$ ) of the profiles along the whole length of the freshly restored bed.

Lüderitz et al. (2004) evaluated the restoration success in the lowland Ihle River. The natural inclination of the river bed of less than $2 \%$ o was to be achieved, which corresponds to the proposed inclination of Slubice River in the Restoration locality 1 . However, persisting deep erosion occurred due to insufficient course restoration, while no development of naturally diversified habitat associated with the river dynamics in the brought out floodplain was manifested. In the process of modeling the effect of selected restoration measures on the restoration of the natural function of the hydrological regime, restoration of alteration of riffles and pools, and a change of the slope, bring a higher effect than modification of the substrate structure (Kasahara, Hill 2008). However, based on the study results, the highest effect is brought by restoration of the meandering, together with addition of coarse sediments to the channel (Kasahara, Hill 2008). Because of risk of deep erosion and high effect of meandering on further river ecosystem development main aim of proposal was focused on length and planform of channel.

Similarly as in these case study's results (Lüderitz et al. 2004; Kasahara, Hill 2008; Kliment et al. 2008), prediction of the hydromorphological status after application of the proposed restoration in the Slubice River confirmed that the 
proposal of a new channel course corresponding to the reference conditions was an essential precondition for improvement of hydromorphological quality elements, however, the responses of biological elements should be perceived.

Lüderitz et al. (2004) recommends expanding hydrobiological survey of the macroinvertebrates, considered as the most suitable for evaluation of the success of small stream restorations, with fishes and macrophytes components. It however appears, that macrophytes are not sensitive enough to changes in the habitat, and their presence depends particularly on hydraulic conditions of the stream and on shading of the channel by plants in the riparian zone (Lüderitz et al. 2004; Sawa, Popek 2011). The effect of the substrate and hydraulic characteristics of the channel are considered as the most significant factors influencing the abundance of macroinvertebrates (Parson, Thoms 2007; Sawa, Popek 2011). Proposed restoration of river bed habitat with variable depth and restoration of river passability provide for diversification of water flow and thus it should represent a precondition for improvement of biological elements status.

The limited potential of recolonization and particularly poor water quality (Jähnig et al. 2010; Sawa, Popek 2011; Sundermann et al. 2011) are considered to be the main reasons of the little effect of restorations on improvement of the macroinvertebrates component. In terms of the effect of restoration on the ecological status, the existence of riparian zones in good state appears to be important, as they reduce the input of nutrients and pesticides into the stream. The riparian zones with bands of 5-30 m width and longer than $1 \mathrm{~km}$ seem to provide the highest efficiency (Parson, Thoms 2007; Matthews et al. 2010; Feld et al. 2011). The creation of new longer meandering course with functional riparian zones a reduction of nutrients inflow should be achieved by proposed restoration.

\section{Conclusions}

It is essential that the ecological survey including hydromorphological survey is carried out before any proposal of restoration as it provides important inputs, and after the restoration application as it allows assessment of restoration effect. The highest improvement of the status of hydromorphological elements in the cultural landscape of Central Europe can be achieved in modified small streams in an extensively used agricultural landscape. Whereas the main rivers are often limited in their options for restoring the new course because complex restoration measures have high cost and several realization difficulties therefore, the improvement of riparian belt and floodplain quality should be supported.

An essential precondition of successful restoration, which leads to improvement in status of hydromorphological elements, is in allowing for natural development of the channel course without stabilization of the banks, restoration of migration 
passability (and if possible transport of sediment), restoration of the variability of depths and widths along the longitudinal profile, and restoration of variability of the cross-section profile in accordance with the channel course (alternation of riffles and pools). The channel dimension designation has to allow for direct overflow into the flood plain during the flood events in non-urbanized areas. This is of crucial importance for sustaining the functions of the restored segment.

Despite high improvement of channel structure, the quality of riparian zone and inundation area (especially land cover and structure) has the significant role among the restoration measures for achievement of good hydromorphological status and support achievement of good ecological status.

\section{References}

ALISON, S.K. (2007): You Can't Not Choose: Embracing the Role of Choice in Ecological Restoration. Restoration Ecology, 15, 601-605.

BOON, P.J., HOLMES, N.T.H., RAVEN, P.J. (2010): Developing standard approaches for recording and assessing river hydromorphology: the role of the European Committee for Standardization (CEN). Marine and freshwater ecosystems, 20, 55-61.

CHMI (2008): Daily precipitation data from hydro stations Hamry, Krucemburk a Vysočina in period 1998-2007.

Committee for Standardization (2004): EN 14614 Water quality - Guidance standard for assessing the hydromorphological features of rivers. Brussels.

ČSN 757221 (1998): Jakost vod - Klasifikace jakosti povrchových vod.

DAVIS, M.A., SLOBODKIN, L.B. (2004): The Science and Values of Restoration Ecology. Restoration Ecology, 12, 1-3.

DUFOUR, S., PIEGAY, H. (2009): From the myth of a lost paradise to targeted river restoration forget natural references and focus on human benefits. River Research and Applications, 25, $568-581$.

FELD, C.K., BIRK, S., BRADLEY, D.C., HERING, D., KAIL, J., MARZIN, A., MELCHER, A., NEMITZ, D., PEDERSEN, M.L., PLETTERBAUER, F., PONT, D., VERDONSCHOT, P.F.M., FRIBERG, N. (2011): From Natural to Degraded Rivers and Back Again: A Test of Restoration Ecology Theory and Practice. Advances in Ecological Research, 44, 119-209.

GANN, G.D., LAMB, D. (2006): Ecological restoration: A mean of conserving biodiversity and sustaining livelihoods (version 1.1). Society for Ecological Restoration International, Tucson, Arizona, USA and IUCN, Gland, Switzerland.

HANNAH, D.M., SADLER, J.P., WOOD, P.J. (2007): Hydroecology and ecohydrology: a potential route forward? Hydrological Processes, 21, 3385-3390.

HMÚ (1970): Hydrologické poměry ČSSR. III. díl. Hydrometeorological institute, Turnov.

JÄHNIG, S.C., BRABEC, K., BUFFAGNI, A., ERBA, S., LORENZ, A.W., OFENBÖCK, T., VERDONSCHOT, P.F.M., HERING, D. (2010): A comparative analysis of restoration measures and their effects on hydromorphology and benthic invertebrates in 26 central and southern European rivers. Journal of Applied Ecology, 47, 671-680.

JANSEN, K., TREPEL, M., MERRITT, D., ROSENTHA, G. (2006): Restoration ecology of river valleys. Basic and Applied Ecology, 7, 383-387. 
JUST, T. et al. (2005): Vodohospodářské revitalizace a jejich uplatnění v ochraně před povodněmi. Český svaz ochránců př́rody, Prague.

KASAHARA, T., HILL, A.R. (2008): Modeling the effect of lowland stream restoration projects on stream-subsurface water exchange. Ecological engineering, 32, 310-319.

KLIMENT, Z., MATOUŠKOVÁ, M., ŠOBR, M., POTU゚ČKOVÁ, M., HUJSLOVÁ, J. (2008): Fluvial dynamics and selected methods of ecohydrological monitoring of restored Sviňovický brook channel. AUC-Geographica, 1-2, 125-144.

LANGHAMMER, J. (2007): HEM. Hydroekologický monitoring. Metodika a manuál pro mapovatele. Charles University in Prague, Prague.

LANGHAMMER, J. (2008): HEM. Hydroekologický monitoring. Charles University in Prague, Prague.

LANGHAMMER, J., VAJSKEBR, V. (2007): Využití GIS pro analýzu a zkrácení ŕíční sítě na základě historických mapových podkladů. In: Langhammer, J. (ed.): Povodně a změny v krajině. Charles University in Prague, Prague, 153-168.

LEUVEN, R.S.E.W., NIENHUIS, P.H. (2001). River restoration and flood protection: controversy or sinergism? Hydrobiologia, 444, 85-99.

LÜDERITZ, V., JÜPNER, R., MÜLLER, S., FELD, C.K. (2004): Renaturalization of streams and rivers - the special importance of integrated ecological methods in measurement of success. An example from Saxony-Anhalt (Germany). Limnologica, 34, 249-263.

MATOUŠKOVÁ, M. (2005): Assessment of the human impact on the river network as a basis for the ecohydrological monitoring of streams. Geographical Review, 129, 35-46.

MATOUŠKOVÁ, M. (2008a): Assessment of the river habitat quality within European Water Framework Directive: Application to different catchments in Czechia. Geografie, 113, 223-236.

MATOUŠKOVÁ, M. (2008b): Ekohydrologický monitoring vodních toků v kontextu Evropské Rámcové směrnice o vodní politice EC2000/60. Charles University in Prague, Prague.

MATOUŠKOVÁ, M., WEISS, A., MATSCHULLAT, J. (2010): Ecological survey of river habitat diversity: trans-boundary cooperation in the Ore Mountains (Krušné hory, Erzgebirge). Geografie, 115, 3, 284-307.

MATTHEWS, J., REEZE, B., FELD, C.K., HENDRINKS, A.J. (2010): Lessons from practice: assessing early progress and Access in river rehabilitation. Hydrobiologia, 655, 1-14.

McBRIDE, M., HESSION, W.C., RIZZO, D.M. (2010): Riparian reforestation and channel change: How long does it take? Geomorphology, 116, 330-340.

NESTLER, J.M., THEILING, C.H., LUBINSKI, K.S., SMITH, D.L. (2010): Reference condition approach to restoration planning. River Research and Applications, 26, 1199-1219.

NEWSON, M.D., LARGE, A.R.G. (2006): "Natural" rivers, "hydromorphological quality" and river restoration: a challenging new agenda for applied fluvial geomorphology. Earth Surface Processes and Landforms, 31, 1606-1624.

ORR, H.G., LARGE, A.R.G., NEWSON, M.D., WALSH, C.L. (2008): A predictive typology for characteristing hydromorphology. Geomorphology, 100, 32-40.

PALMER, M.A. et al. (2005): Standards for ecologically successful river restoration. Journal of Applied Ecology, 42, 208-217.

PARSON, M., THOMS, M.C. (2007): Hierarchical patterns of physical-biological associations in river ecosystems. Geomorphology, 89, 127-146.

RAVEN, P.J., HOLMES, N.T.H., VAUGHAN, I.P., DAWSON, F.H., SCARLETT, P. (2010): Benchmarking habitat quality: observations using River Habitat Survey on near-natural streams and rivers in northern and western Europe. Marine and freshwater ecosystems, 20, 13-30. 
ROZKOŠNÝ, M. et al. (2007): Výzkum vodních ekosystémů v rámci povodí. Závěrečná souhrnná zpráva projektu VaV/SL/8/59/04. Ministry of the environment of the Czech Republic, Brno. SAWA, K., POPEK, Z. (2011): Analysis of the connections between hydromorphological conditions and biocenotic diversity on the example of the Zwoleńka River. Land Reclamation, 43, 173-184.

ŠÍPEK, V., MATOUŠKOVÁ, M., DVOŘÁK, M. (2010): Comparative analysis of selected hydromorphological assessment methods. Environmental Monitoring Assessment, 169, 309-319.

SUNDERMANN, A., ANTONS, C., CRON, N., LORENZ, A. W., HERING, D., HAASE, P. (2011): Hydromorphological restoration of running waters: effects on benthic invertebrate assemblages. Freshwater Biology, 56, 1689-1702.

VANNOTE, R.L., MINSHALL, G.W., CUMMINS, K.W., SEDELL, J.R., CUSHING, C.E. (1980): The River Continuum Concept. Canadian Journal of Fisheries and Aquatic Sciences, 37, 130-137.

VAUGHAN, I.P., DIAMOND, M., GURNELL, A.M., HALL, K.A., JENKINS, A., MILNER, N.J., NAYLOR, L.A., SEAR, D.A., WOODWARD, G., ORMEROD, S.J. (2009): Integrating ecology with hydromorphology: a priority for river science and management. Marine and freshwater ecosystems, 19, 113-125.

VERDONSCHOT, P.F.M. (2000): Integrated ecological assessment methods as a basis for sustainable catchment management. Hydrobiologia, 422-423, 389-412.

WADE, P.M., LARGE, A.G.R., DE WAAL, L.C. (2000): Rehabilitation of Rivers. Principles and Implementation. John Wiley \& Sons, Chichester.

Water Framework Directive. Directive 2000/60/EC of the European parliament and of the Council of $23^{\text {st }}$ October 2000 establishing a framework for Community action in the field of water policy. Official Journal of the European Communities, I., 327/1, Luxemburg.

WEISS, A., MATOUŠKOVÁ, M., MATSCHULLAT, J. (2008): Hydromorphological assessment within the EU-Water Framework Directive - trans-boundary cooperation and application to different water basins. Hydrobiologia, 603, 53-72.

ZALEWSKI, M. (2006): Ecohydrology - an interdisciplinary tool for integrated protection and management of water bodies. Arch. Hydrobiol. Suppl., 158, 613-622.

ZALEWSKI, M. (2008): Rationale for the "Floodplain Declaration" from environmental conservation toward sustainability science. Ecohydrology \& hydrobiology, 8, 107-113.

\section{SHRNUTí}

\section{Zlepšení kvality fyzického habitatu vodních toků jako odezva na revitalizační opatření}

Nárůst antropogenního ovlivnění a celková degradace přirozených habitatů vodních ekosystémů vyvolaly potřebu porozumět širokému spektru dopadů na jejich kvalitu, vyhodnotit tyto změny a nastavit opatření, která by znovu vedla k dosažení dobrého stavu vod. Rámcová směrnice o vodách 2000/60/ES požaduje dosažení dobrého ekologického stavu vod, který je klasifikován na základě biologických, hydromorfologických, chemických a fyzikálně chemických složek kvality. Klasifikace jednotlivých složek kvality je založena na porovnání současného stavu s referenčními podmínkami, ve smyslu původních nenarušených podmínek jednotlivých kvalitativních složek. Cílem úspěšné revitalizace je tedy návrh a realizace hydromorfologických opatření, která při odpovídající kvalitě chemických a fyzikálně chemických složek povedou k dosažení dobrého ekologického stavu. 
Nezbytnou součástí návrhu revitalizačních opatření je tedy stanovení regionálních hydromorfologických referenčních podmínek a vyhodnocení hydromorfologického stavu. Hydromorfologická kvalita zájmového toku Slubice a údolní nivy byla hodnocena metodou HEM - Hydroekologický monitoring (Langhammer 2007, 2008). Terénním průzkumem bylo vyhodnoceno v každém vymezeném úseku 17 parametrů rozdělených do 4 mapovaných zón. Výsledná hydromorfologická kvalita hodnocených úseků byla zařazena do jedné z 5 tř́id hydromorfologického stavu. Regionální hydromorfologické referenční podmínky jako předpoklad pro formulování cílového stavu navrhovaných revitalizačních opatření byly stanoveny na základě detailního terénního průzkumu a měření řady hydromorfologických charakteristik v přirozených úsecích zájmového povodí Slubice. Analýza změn délky a tvaru ř́iční sítě byla založena na porovnání historických map Stabilního katastru Čech v měřítku 1:2880 a současných katastrálních map zájmového povodí Slubice. Jako podklad pro návrh revitalizačních opatření byla dále hodnocena variabilita odtoku, kapacita koryta, kvalita vody a vegetace koryta a údolní nivy.

Pro návrh revitalizace byly vybrány dvě lokality s nejhorším výsledným hodnocením hydromorfologického stavu, významně postižené zahloubením, napřímením a opevněním s nevhodnou kapacitou koryta i sklonem trasy. Záměrem bylo propojení přirozených úseků toku.

Výsledky analýzy změn tvaru a délky říční sítě prokázaly zkrácení o 31,4 \% na horním toku Slubice a o 48,8 \% na dolním toku. V rámci hydromorfologického monitoringu byla zjištěna značná modifikace koryta toku včetně trasy, ale poměrně dobrá kvalita údolní nivy. Celkový hydromorfologický stav toku zjištěný aplikací metody HEM byl určen jako průměrný (3. HS) pro 49,5\% délky toku, ve velmi dobrém a dobrém stavu bylo označeno 45,9\% délky toku. Kvalita vody byla v zájmovém povodí hodnocena zejména s ohledem na limitující potenciál kvality biologických složek. Největším problémem kvality vody ve sledovaných profilech byla kontaminace nutrienty z plošných zdrojů znečištění. S ohledem na výše uvedené skutečnosti byla v souladu se stanovenými referenčními podmínkami navržena nová meandrující trasa koryta včetně výpočtů sklonů, kapacity koryta a variability podélných i př́íných profilů. $Z$ důvodu značného rizika hloubkové eroze a vysokého efektu meandrování byl v rámci revitalizačního návrhu důraz kladen zejména na délku a trasu koryta. Návrh nového koryta byl zasazen do existující nivy a doplněn návrhem břehových porostů. Kritéria hodnocení úspěšnosti revitalizace byla zvolena v souladu s nastavením hodnocení metodiky HEM (Langhammer 2008) a následně byl vypočítán hydromorfologický stav pro simulované podmínky. Aplikací metody HEM na simulované podmínky bylo zjištěno významné zlepšení stavu zóny koryta (až o 3 třídy hydrologického stavu), vzhledem k očekávanému zlepšení morfologických charakteristik koryta došlo také ke zlepšení zóny hydrologický režim (o 1-2 třídy HS).

Simulací podmínek po aplikaci navržených revitalizačních opatření při zohlednění reálných rizik realizace revitalizace bylo zjištěno prokazatelné zlepšení stavu hydromorfologických složek v obou lokalitách. Hydromorfologický průzkum a stanovení regionálních referenčních podmínek před návrhem opatření na zlepšení hydromorfologického stavu poskytuje podklady nezbytné pro návrh opatření i následné vyhodnocení efektu opatření.

Ačkoli jsou revitalizační opaření značně individuální, základním předpokladem pro zlepšení stavu hydromorfologických složek je obnova přirozené trasy koryta bez stabilizace břehů a dna, obnova migrační průchodnosti, variability hloubek a šířek koryta v podélném i příčném profilu. Navzdory významu komplexní revitalizace koryta toku lze při posouzení efektu i částečnou revitalizací koryta toku dosáhnout zlepšení hydromorfologického stavu. Na všech vodních tocích lze dále podporovat dosažení dobrého ekologického stavu prostřednictvím opatření na zlepšování kvality př́břežní zóny a údolní nivy, zejména typem krajinného pokryvu a strukturou vegetace v příbřežní zóně. 
Obr. 1 Lokalizace, profily pro hodnocení kvality vod a krajinný pokryv povodí Slubice v roce 2009. Legenda pro profily hodnocení kvality vod: 1 - Slubice (horní tok), 2 - Černý potok, 3 - Slubice (střední tok), 4 - Slubice (dolní tok), 5 - Barchanecký potok, 6 - Chrudimka. Zdroj: letecké snímky GEODIS 2009, terénní průzkum.

Obr. 2 Vybrané zaměřené př́čné profily (jejich maximální hloubka a plocha průtočného profilu) v referenčních lokalitách a jejich srovnání se současnými a navrženými příčnými profily v lokalitách k revitalizaci.

Obr. 3 Výsledky hodnocení hydromorfologického stavu Slubice na základě aplikace metody HEM (Langhammer 2007, 2008), vykresleno v podélném profilu Slubice.

Obr. 4 Letecký snímek části Referenční lokality 1 a Lokality k revitalizaci 1 - detail původního koryta, návrh propojení původních koryt a současné trasy toku. Zdroj: letecké snímky GEODIS 2009.

Obr. 5 Detail porovnání současného napřímeného koryta v Lokalitě k revitalizaci 1, původní koryto, které se zachovalo ve dvou oddělených částech (detail A a B - dohromady Referenční lokalita 1) a návrh trasy toku v Lokalitě k revitalizaci 1.

Obr. 6 Změny v délce a tvaru dvou vybraných úseků (úsek Slubice_1 v Lokalitě k revitalizaci 2, úsek Slubice_4 v Lokalitě k revitalizaci 1). Porovnání původní trasy z historických map (vlevo) se současnou trasou z katastrálních map (uprostřed) a s navrhovanou trasou (vpravo).

Obr. 7 Současná délka z katastrálních map (šedě) a změny oproti původní délce z historických map (černě) pro 7 vybraných úseků říční sítě povodí Slubice. Vybrané úseky (4 na Slubice, 2 na Barchaneckém potoce, 1 na Černém potoce) byly číslovány od pramene k ústí (obr. 6).

Obr. 8 Závislost mezi koncentrací $\mathrm{N}^{-\mathrm{NO}_{3}^{-}}$(vlevo), $\mathrm{N}-\mathrm{NH}_{4}^{+}$(vpravo) a odpovídajícími naměřenými průtoky na sledovaných profilech (zvýrazněna je mezní hodnota pro IV. a V. třídu jakosti vody podle ČSN 757221 ).

Obr. 9 Konzumpční a rychlostní křivka pro navržené příčné profily v přímé trase (brodu) pro Lokalitu k revitalizaci 1 (vlevo) a pro Lokalitu k revitalizaci 2 (vpravo).

Obr. 10 Hydromorfologický stav Slubice v Lokalitě k revitalizaci 1 hodnocený na základě aplikace metody HEM (Langhammer 2007; Langhammer 2008) - současný stav a predikce stavu po návrhu revitalizačních opatření včetně detailu hodnocení jednotlivých mapovaných zón a celkového stavu.

\section{ACKNOWLEDGEMENTS}

This research was conducted as part of research projects GAČR 13-32133S "Headwaters retention potential with respect to hydrological extremes", SVV 3300-244-2600781 "Physic-geographical processes" and PRVOUK-43 Geography. 